Arhe XVI, 32/2019

UDK 165.741 Peirce C. S.

$165.6 / 8$

DOI https://doi.org/10.19090/arhe.2019.32.219-243

Originalni naučni rad

Original Scientific Article

\author{
DUŠAN MILENKOVIĆ ${ }^{1}$ \\ Univerzitet u Nišu, Filozofski fakultet
}

\title{
„METODOLOŠKI POJAM ISTINE“ I EPISTEMOLOŠKE TENDENCIJE U KLASIČNOM PRAGMATIZMU Č. S. PERSA I V. DŽEMSA
}

Sažetak: U radu se analizira Habermasova interpretacija Persovog pragmatizma i njegove težnje ka primeni teorijskih dometa naučne metodologije $u$ rešavanju problema koji pripadaju domenu epistemologije. U skladu sa ovom interpretacijom, u radu se pokazuje kako Pers u svojim najpoznatijim tekstovima ne uspeva da ostane $\mathrm{u}$ okvirima teze o promišljanju saznanja iz perspektive metoda naučnog istraživanja, bez obzira na njegovu otvorenu kritiku tradicionalne filozofije. Iako sam Habermas ne govori u knjizi Saznanje i interes o učenju Vilijama Džemsa, u radu se razmatra u kojoj meri ovaj autor takođe zastupa tezu o „metodološkom pojmu istine“, kako u svojoj kritici tradicionalne filozofije, tako i u stavovima u kojima izlaže sopstvenu teoriju saznanja. Rad se približava zaključku da se ni u Persovoj, ni u Džemsovoj filozofiji ne može pronaći Habermasov „dosledni pragmatizam“, budući da oba autora posežu za teorijskim rešenjima preuzetim iz tradicionalne epistemologije, ne ostajući u okvirima zastupanja „metodološkog pojma istine“.

Ključne reči: Č. S. Pers, J. Habermas, V. Džems, pragmatizam, metodološki pojam istine

\section{UVOD}

U svojoj poznatoj knjizi Saznanje $i$ interes, Jirgen Habermas (Jürgen Habermas) dublje razmatra jednu od ključnih odlika takozvanog „klasičnog pragmatizma“ - usmerenost mislilaca ove orijentacije ka rešavanju filozofskih problema uz pomoć teorijskih obrazaca naučne

\footnotetext{
${ }^{1}$ E-mail adresa autora: dusan.milenkovic@ filfak.ni.ac.rs
} 
metodologije. ${ }^{2}$ Razmatrajući u kojoj meri se ova teorijska tendencija može pronaći u filozofskom učenju rodonačelnika pragmatizma, Čarlsa Sandersa Persa (Charles Sanders Peirce), Habermas smatra da pragmatistička primena naučne metodologije u promišljanju problema saznanja predstavlja jedan primer prevazilaženja tradicionalnih epistemoloških obrazaca mišljenja u korist razmatranja saznanja iz perspektive teorijskih dometa metodologije naučnog istraživanja. ${ }^{3}$ Neopragmatistički mislilac smatra da se ova promena paradigme dešava već sa pozitivizmom, na temelju koga pragmatizam nastaje. ${ }^{4} \mathrm{U}$ tom smislu, pragmatizam je „dosledan“ (der konsequente Pragmatismus) ukoliko u razmatranju epistemoloških problema ne poseže za tradicionalnim filozofskim rešenjima, već ostaje u domenu primene metodološke teorijske aparature. ${ }^{5}$ Tako će ovaj teoretičar govoriti o „metodološkom pojmu istine“ nasuprot (tradicionalnom) epistemološkom, pa će svoje tumačenje Persove filozofije izložiti upravo uz pomoć ovog razlikovanja. ${ }^{6}$

Iako ne govori o metodološkom karakteru saznanja u klasičnom pragmatizmu, već se zadržava na pragmatističkoj kritici tradicionalne epistemologije, Ričard Rorti (Richard Rorty) iznosi stavove koji u srpskom prevodu knjige Konsekvence pragmatizma zadobijaju terminološko oblikovanje gotovo identično Habermasovom. Naime, u jednoj eksplikaciji pragmatističkog pristupa filozofiji, Rorti govori o „dosledno sprovedenom pragmatizmu“ (thorough-going pragmatism) ${ }^{7}$

${ }^{2}$ Up. C. Legg, C.Hookway, "Pragmatism", u:The Stanford Encyclopedia of Philosophy (Spring 2019 Edition), Edward N. Zalta (ur.), https://plato.stanford.edu/archives/spr2019/entries/pragmatism.

${ }^{3}$ J. Habermas, Saznanje i interes, str. 99.

${ }^{4}$ Ibid., str. 99-102.

5 J. Habermas, Saznanje i interes, Nolit, Beograd, 1975, str. 137. J. Habermas, Erkenntnis und Interesse, Suhrkamp, Frankfurt am Main, 1991, str. 131.

${ }^{6}$ Ibid., str. 127.

7 R. Rorty, Consequences of Pragmatism, University of Minessota Press, Minneapolis, 1994, str. 150-151. R. Rorti, Konsekvence pragmatizma, Nolit, Beograd, 1992, str. 290. Up. i Charles Guignon, David R. Hiley, „Introduction Richard Rorty and Contemporary Philosophy“ u: C. Guignon, D. R. Hiley (ur.), 
kao o učenju koje odustaje od potrage za konačnom istinom o stvarnosti, potrage koju Rorti pripisuje mnogim tradicionalnim filozofskim pozicijama, ali i nekritički prihvaćenoj pozitivističkoj koncepciji naučnog razvoja. ${ }^{8}$ Do formulacija sličnih Habermasovim, Rorti je možda došao pod neposrednim uticajem Habermasove kritike Persa. Međutim, Rorti u knjizi Konsekvence pragmatizma navodi da ne sledi Habermasovo razumevanje pragmatizma, smatrajući da Habermasovo povezivanje pragmatizma i pozitivizma nije sasvim opravdano. ${ }^{9}$ Ukazujući na razlike između pragmatističkih koncepcija i tradicionalne epistemologije, Rorti čak tvrdi i to da Džems i Djui zapravo nemaju nikakvu „teoriju istine““, 10 već potpuno odbacuju tradicionalni filozofski zahtev za određenim epistemološkim opredeljenjem ili filozofskim utemeljenjem neke druge teorijske discipline: „oni [pragmatisti, D. M.] bi prosto voleli da promene temu“. ${ }^{11}$ Svojom interpretacijom pragmatizma Rorti gotovo potpuno eliminiše epistemološku problematiku iz „dosledno sprovedenog“ pragmatizma, a zadatke pragmatistički orijentisanih filozofa pronalazi u rešavanju konkretnih problema u jednoj društvenoj zajednici. ${ }^{12}$

Imajući u vidu težnje klasičnog pragmatizma ka rešavanju epistemoloških problema uz pomoć teorijskih obrazaca naučne metodologije, kao i Habermasov i Rortijev stav o tome da u klasičnom pragmatizmu postoji otklon od tradicionalne epistemologije, razmotrićemo u kojoj meri su autori klasičnog pragmatizma ostvarili pomenute teorijske težnje mimo korišćenja teorijskih dometa tradicionalne epistemologije, koju, kao što će biti vidljivo u nastavku rada, oštro kritikuju. Analizom samih filozofskih postavki Persa i Džemsa, u ovom radu se traga za istraživačkim karakterom saznanja u pragmatizmu, i to saznanja uzetog $u$ najširem smislu, koji se saznanju obično pridaje kada se govori o „teoriji saznanja“; u radu se zatim traga

Richard Rorty, Contemporary Philosophy in Focus, Cambridge University Press, Cambridge, 2003, str. 13.

${ }^{8}$ R. Rorti, Konsekvence pragmatizma, str. 50-53.

${ }^{9}$ Up. Ibid., str. 54.

${ }^{10}$ Ibid., str. 303.

${ }^{11}$ Ibid., str. 49.

${ }^{12}$ Ibid., str. 86-87, 91-92, 321-322. 
za „doslednošću“ koju pomenuti interpretatori pragmatizma očekuju od teorijskih pozicija ovih pragmatističkih filozofa. Zbog ograničenja ovog rada, razmatranje Djuijevog razumevanja istraživačkog karaktera iskustva, izloženog u knjizi Logika, teorija istraživanja, ostavlja se za neku drugu priliku. ${ }^{13}$

\section{ISTRAŽIVAČKI KARAKTER SAZNANJA U PERSOVOM PRAGMATIZMU}

Ispitajmo da li se Habermasova teza o „metodološkom pojmu istine“, odnosno, istraživačkom karakteru saznanja u klasičnom pragmatizmu, može direktno primeniti na sam sadržaj Persovih filozofskih tekstova. Svoje čuvene eseje „Učvršćivanje verovanja“ i „Kako da svoje ideje učinimo jasnim“, u kojima svoje učenje još uvek ne naziva „pragmatizmom“ (odnosno ,pragmaticizmom“, kao u svojim kasnijim tekstovima), ${ }^{14}$ Pers započinje neposrednim ukazivanjem na važnost logike u svakodnevnom životu, filozofskom promišljanju i naučnom istraživanju. ${ }^{15}$ Ukoliko od pomenutih tekstova očekujemo da nam prikažu osnovne motive Persovog pragmatističkog učenja uz pomoć uspostavljanja odgovarajućeg odnosa pragmatizma i naučne metodologije, Persovo razmatranje osnovnih problema logike u ovim tekstovima može nam izgledati kao čudna okolnost, pa je najpre potrebno pozabaviti se njegovim razumevanjem same logike. Razmatranjem Persovog stava o ulozi logike, predstavićemo i osnovne stavove ovog teoretičara na kojima se temelji njegova misao o istraživačkom karakteru saznanja.

Pers smatra da razvoj logike neposredno zavisi od stanja nauke u jednoj epohi. ${ }^{16}$ Naučna metodologija se ne svodi samo na proučavanje posmatračkih i eksperimentatorskih aktivnosti, već se u naučnoj

${ }^{13}$ Up. Dž. Djui, Logika, teorija istraživanja, Nolit, Beograd, 1962, str. 59-78. Up. i Milenković, D. „Djuijevo pragmatističko poimanje umetnosti u knjizi Art as Experience", Arhe 26/2016, str. 144-147.

${ }_{14}$ Č. S. Pers, Izabrani spisi, BIGZ, Beograd, 1993, str. 195-196.

${ }^{15}$ Č. S. Pers, Pragmatizam, str. 7-10, 32-33.

${ }^{16}$ Ibid., str. 8-10. 
delatnosti sama logika afirmiše. ${ }^{17}$ Ona ispunjava svoju teorijsku misiju ukoliko osigurava da se naše metode u nauci ne svedu na nekritičko usvajanje određenog tumačenja stvarnosti, pa time logika postaje garant istraživačkog karaktera naučnih metodâ; ${ }^{18}$ na ovaj način, Pers anticipira Djuijev pragmatizam. ${ }^{19}$ Međutim, izgleda da Pers samu logiku smatra jednim od derivata epistemoloških operacija svesti - operacija kojima pridaje istraživački karakter. ${ }^{20}$ Govoreći o odnosu premisa i zaključka, Pers najpre u duhu Hjuma (David Hume) napominje da se ovaj odnos zasniva na jednoj „navici uma“, da bi sledećom intervencijom logičku dihotomiju istinitosti i lažnosti zamenio terminološkim parom „sumnja“ i „verovanje“. ${ }^{21} \mathrm{U}$ zastupanju ove teze Pers odlazi toliko daleko da sintagmu ,istinito verovanje“ smatra pleonastičnom: „Mi, međutim, mislimo da je svako naše verovanje istinito, a tako nešto je, zaista, obična tautologija“. 22

U ovom kontekstu Pers već govori u saznanju kao istraživanju: „Nadražaj sumnje prouzrokuje borbu da se dostigne stanje verovanja. Ovu borbu ću označiti terminom istraživanje“. ${ }^{23}$ Različite metode „učvršćivanja verovanja“ $u$ istoimenom tekstu on direktno upoređuje sa naučnom metodom $\mathrm{i}$ ističe njena preimućstva, a zatim preuzima $\mathrm{i}$ primenjuje ove stavove u tekstu „Kako da svoje ideje učinimo jasnim““. ${ }^{24}$ Zatim, u kasnijem tekstu „Šta pragmatizam jeste“ govori i o saznajnom subjektu kao „eksperimentatoru“, pri čemu se struktura eksperimentalne metode neposredno poistovećuje sa strukturom čina saznanja. ${ }^{25}$ Ovim

\footnotetext{
17 Ibid.

${ }^{18}$ Ibid., str. 11.

${ }^{19}$ Up. Dž. Djui, Logika, teorija istraživanja, str. 61-62. Beograd, 1966, str. 22-23.

${ }^{21}$ C. S. Pers, Pragmatizam, str. 11, 14-16.

${ }^{22}$ Ibid., str. 16.

${ }^{23}$ Č. S. Pers, Pragmatizam, str. 15, Up. i Ibid, str. 16, 17.

${ }^{24}$ Ibid., str. 22-28, 34-40.

${ }^{25}$ Č. S. Pers, Izabrani spisi, str. 203-205.
}

20 Drugačije tumačenje statusa logike u Persovom mišljenju zagovara Miladin Životić, smatrajući da se logika u Persovom mišljenju pre svega mora smatrati formalnom logikom, a ovu tezu opravdava povezivanjem Persovog pragmatizma i njegove semiologije. M. Životić, Pragmatizam i savremena filozofija, Nolit, 
koracima ka epistemologiji Pers pokušava da predstavi svakodnevno iskustvo, metodologiju i logiku kao rezultate različitih istraživačkih procesa, od kojih se svaki ponaosob može izložiti iz perspektive odnosa sumnje i verovanja u svesti subjekta saznanja, odnosno istraživanja.

U razradi teze o istraživačkoj prirodi saznanja Pers zastupa i mišljenje prema kome odnos sumnje i verovanja u subjektu saznanja kao istraživanja ima i jednu specifično društvenu dimenziju. Saznanje u istraživačkom obliku uzima u razmatranje i verovanja drugih pripadnika jedne zajednice; na ovaj način, Pers izdvaja važnost društvenog života za pragmatističko poimanje znanja, važnost koju će kasnije istaći Djui, ${ }^{26}$ ali i Rorti, ${ }^{27}$ koji Persov udeo u razvoju pragmatizma nedvosmisleno negira. Američki neopragmatistički mislilac ograničava svoj govor o Persu na sledeću tvrdnju: „Njegov doprinos pragmatizmu je samo u tome što mu je dao ime i što je podsticao Džejmsa“ “. ${ }^{28}$ Sa druge strane, kada Habermas u kontekstu razmatranja Persove filozofije kaže da je istina ,javna“, to budi jače asocijacije spram Habermasovog isticanja važnosti komunikacije nego spram Persove filozofije; međutim, u tom slučaju se upravo radi o Persovim rečima, iskazanim prilikom naglašavanja društvene dimenzije saznanja kao istraživanja, iako se, začudo, u Habermasovom delu na ovom mestu ne referiše na sâm Persov tekst. ${ }^{29}$

Tek nakon ukazivanja na istraživački karakter logike i epistemologije, Pers prelazi na kritiku tradicionalne epistemologije i formulisanje poznate „pragmatističke maksime“, koja u tekstu „Kako da svoje ideje učinimo jasnim“ još uvek ne nosi ovaj naziv, već se izriče u kontekstu upoređivanja tradicionalnih epistemoloških stanovišta i teze o istraživačkoj prirodi saznanja. ${ }^{30}$ Budući da se prilikom formulisanja pragmatističke maksime Pers direktno poziva na prethodno izrečene stavove o istraživačkom karakteru saznanja i interakciji sumnje i verovanja u svesti subjekta saznanja kao istraživanja, ova maksima se može smatrati upravo stavom kojim se zastupa istraživačka priroda

\footnotetext{
${ }^{26}$ Dž. Djui, Logika, teorija istraživanja, str. 98-99.

${ }^{27}$ R. Rorti, Konsekvence pragmatizma, str. 86-94.

${ }^{28}$ Ibid., str. 304.

${ }^{29}$ J. Habermas, Saznanje i interes, str. 135. Č. S. Pers, Pragmatizam, str. 23.

${ }^{30}$ Ibid., str. 37-40.
} 
saznanja. Poznatu krilaticu Pers formuliše kako bi saznajni čin zaštitio od uticaja neosnovanih metoda koje pronalazi u ljudskoj istoriji ili u tradicionalnoj filozofiji - metode istrajnosti, metode autoriteta i apriorne metode. $^{31}$

Razumevanje konteksta u kome Pers formuliše pragmatističku maksimu važno je da bi se pragmatističko mišljenje jasno razlikovalo od rigidnog tumačenja osnovnih stavova ovog mišljenja, prema kome bi pragmatizam mario samo za ona znanja iz kojih se može neposredno izvući svojevrsna praktična korist. U korišćenom prevodu Persovog spisa „Kako da svoje ideje učinimo jasnim“ (koji je sačinio Dušan Veličković), maksima glasi: „Razmotrimo kakve posledice, koje na shvatljiv način mogu imati praktično značenje, smatramo da predmet naše predstave treba da ima. Tada naša predstava o ovim posledicama čini celinu naše predstave o ovom objektu“. ${ }^{32}$ Međutim, formulacija pragmatističke maksime zadobila je u ovom prevodu normativni karakter koji ne odgovara Persovom pragmatističkom učenju. Pored toga što $u$ originalnom Persovom tekstu ${ }^{33}$ ne nalazimo nedvosmislenu jezičku formulaciju koja bi ukazala na normativni karakter ove tvrdnje (pa je dodavanje ovog ,treba da“" posledica tumačenja teksta), ovako prevedena pragmatistička maksima unosi u Persovo učenje izvesnu konotaciju koju Pers u navedenim tekstovima nedvosmisleno odbacuje. Ukoliko u istraživačkom aktu saznanja posežemo za posledicama koje predmet „treba da ima“, onda, rečeno jezikom Persove filozofije, najverovatnije pristupamo predmetu sa određenim prethodnim ubeđenjem, sa već „učvršćenim verovanjem“, koje potiče od nas samih, ili od nekog spoljašnjeg autoriteta (tradicije, crkve, politike i tome slično), a ne sa nepristrasnom istraživačkom namerom. O ovom aspektu Persovog učenja ubrzo ćemo govoriti. Pragmatistička maksima se može naći i u kasnijem Persovom tekstu „Šta pragmatizam jeste“. Korišćeni prevod ovog Persovog teksta priredio je drugi prevodilac (Radoslav Konstantinović), a

\footnotetext{
${ }^{31}$ Ibid., str. 18-19, 20, 22-23.

${ }^{32}$ Ibid., str. 40.

${ }^{33}$ Up. formulaciju pragmatističke maksime na engleskom jeziku u: Č. S. Pers, Izabrani spisi, str. 201.
} 
u ovom prevodu pragmatistička maksima nema problematični normativni karakter. Prevod ovde glasi: „Razmotrite kakve posledice, za koje bi se moglo zamisliti da imaju praktičnog značaja, vi zamišljate da ima predmet vaše zamisli. Onda vaša zamisao o tim posledicama predstavlja celokupnu vašu zamisao toga predmeta““. ${ }^{34}$

Prema Persovom ubeđenju, apriorna metoda u filozofiji sledi iste obrasce kao metode autoriteta $\mathrm{i}$ istrajnosti u religiji ili političkoj delatnosti, pri čemu se, umesto autoriteta Boga ili vladara, određeno verovanje utemeljuje pozivanjem na autoritet razuma. ${ }^{35}$ Međutim, iako Pers ovde problematizuje izvođenje određenih filozofskih stavova iz prirode razuma (pa su Platon i Dekart u centru Persove pažnje), stiče se utisak da je Persova kritika apriorne metode samo još jedan povod za njegovu kritiku filozofije uopšte, nezavisno od nekog specifičnog filozofskog opredeljenja. Upravo se u ovim aspektima Persovog učenja nalazi osnov za već pomenuti otklon od epistemologije koji od klasičnog pragmatizma očekuju Habermas i Rorti. Ne samo da Pers otvoreno odbacuje i „materijalističku i spiritualističku filozofiju“ ${ }^{36}$ već se u tekstu „Šta pragmatizam jeste“ ograđuje od svakog filozofskog pristupa koji se zasniva na određenim početnim tačkama filozofiranja - kako od pozicijâ koje se uzdaju u izvesnost urođenih ideja ili univerzalnost ogoljenog „stanja duha“, tako i od filozofijâ koje smatraju da je, metaforički rečeno, jedinicu mere filozofiranja moguće pronaći u „prvim čulnim utiscima“. ${ }^{37}$ Pers smatra da je nemoguće sagledati stvari sa ogoljenog filozofskog stanovišta te vrste, sa koga bismo uspostavili svojevrstan saznajni odnos prema samoj stukturi svesti ili neposredno datom čulnom iskustvu. On ovakve pokušaje smatra uzaludnom filozofskom invencijom koja nam ništa ne govori o svakodnevnom odnošenju prema predmetu iskustva, čak i u slučajevima kada filozof neposredno sugeriše određene metode uz pomoć kojih je moguće sagledati stvari iz odgovarajuće teorijske

\footnotetext{
${ }^{34}$ Ibid.

${ }^{35}$ Č. S. Pers, Pragmatizam, str. 22, 23, 30.

${ }^{36}$ Ibid., str. 22.

${ }^{37}$ Ibid., str. 16. Č. S. Pers, Izabrani spisi, str. 197.
} 
perspektive. ${ }^{38}$ Zbog toga će se Persova kritika tradicionalne filozofije posebno ustremiti ka kartezijanskoj „metodskoj sumnji“: on kartezijanskim filozofima postavlja sledeće pitanje: „da li sumnjom nazivate to kada na listu papira napišete da sumnjate? ${ }^{\text {(39 }}$ Nasuprot tome, prema Persu, pragmatizam postupa onako kako se postupati mora: s obzirom na to da nije moguće s pravom transcendirati sopstveno životno iskustvo kao čitav konglomerat usvojenih verovanja, potrebno je promišljati samo saznanje iz perspektive prethodno usvojenih obrazaca postupanja. ${ }^{40}$ Subjekt saznanja je nemoguce rasteretiti svih usvojenih verovanja, pa je isključena mogućnost univerzalne metodske sumnje; pojedinačna verovanja subjekt može problematizovati u aktu saznanja kao istraživanja jedino $\mathrm{u}$ određenom ,horizontu neproblematizovanih ubeđenja“, kako to Habermas formuliše, poigravajući se sa fenomenološkom terminologijom. ${ }^{41}$

\section{DRUGE EPISTEMOLOŠKE TENDENCIJE U PERSOVOM PRAGMATIZMU I HABERMASOVA KRITIKA PERSOVOG UČENJA}

Istovremeno sa zastupanjem izloženih teza o istraživačkom karakteru saznanja, Pers pragmatizmu pripisuje i prihvatanje određene „pročišćene filozofije“: navodeći razlike između pragmatizma i pozitivizma, ovaj teoretičar nam govori da pragmatizam prihvata i „glavninu naših instinktivnih verovanja“, kao i „naglašavanje istinitosti sholastičkog realizma“. ${ }^{42}$ Pomenuti Persov stav o potrebi za usvajanjem instinktivnih verovanja relevantan je za promišljanje epistemoloških tendencija $u$ učenju rodonačelnika pragmatizma, jer već ona dovodi $u$ pitanje Persovu tezu o istraživačkom karakteru saznanja. Ako postoje određena instinktivna verovanja, onda su ona $u$ svojevrsnoj privilegovanoj poziciji $\mathrm{u}$ odnosu na neka druga verovanja, koja se $\mathrm{u}$

\footnotetext{
${ }^{38}$ Ibid., str. 197-198.

${ }^{39}$ Ibid., str. 197.

${ }^{40}$ Ibid., str. 197, 198.

${ }^{41}$ J. Habermas, Saznanje i interes, str. 130.

${ }^{42}$ C. S. Pers, Izabrani spisi, str. 202.
} 
istraživačkom činu saznanja mogu dovesti u pitanje - Pers ovom tezom gotovo da prihvata tradicionalnu racionalističku tezu o postojanju određenih urođenih ideja. Sa druge strane, Persovo povezivanje realizma u smislu sholastičkog spora oko univerzalija sa istraživačkim karakterom saznanja u pragmatističkom učenju može se smatrati bar proizvoljnim, ako ne i problematičnim. Prema Edvardu Muru (Eduard C. Moore), Persov sholastički realizam i pragmatizam su dva učenja sasvim nezavisna jedno od drugog, uprkos Persovom insistiranju na njihovoj direktnoj povezanosti. ${ }^{43}$

Nadalje, iako će Pers započeti tekst „Šta pragmatizam jeste“ odbacivanjem mogućnosti „postojanja neiskustvene realnosti“, $\mathrm{u}$ istom tekstu će formulisati i stavove poput definisanja „realnog“ kao onog ,što ima takve i takve odlike, bez obzira na to da li iko misli da ono te odlike ima ili nema“. ${ }^{44}$ Još direktniju potvrdu za Persovu sklonost ka zastupanju epistemološkog realizma nalazimo u starijem tekstu „Učvršćivanje verovanja“, u kome klasični pragmatista na jednom mestu neočekivano brani tvrdnju „da postoje realne stvari“, a u prvom od argumenata koje stavlja u prilog ovoj tvrdnji gotovo otvoreno potvrđuje da ova problematika nije u ingerencijama saznanja koje bi se zasnovalo na istraživačkim procedurama: „Ako se ne može prihvatiti da istraživanje potvrđuje postojanje realnih stvari, ono, bar, ne vodi suprotnom zaključku“. ${ }^{45}$ Ukoliko pozicija koja zastupa tezu o saznanju kao istraživanju kapitulira pred pitanjem bivstvovanja predmeta saznanja, a rešenje ovog problema traži u svojevrsnim ,instinktivnim verovanjima“ ili teorijskim intervencijama tradicionalne epistemologije, onda se možemo zapitati da li je Persov pragmatizam svojim stavovima o istraživačkom karakteru saznanja zaista sproveo određenu promenu paradigme od tradicionalnog epistemološkog ka metodološkom razumevanju saznanja.

${ }^{43}$ Edward C. Moore, "The Scholastic Realism of C. S. Peirce", u: Philosophy and Phenomenological Research, Vol. 12, No. 3 (Mart 1952), str. 406-417.

${ }^{44}$ Č. S. Pers, Izabrani spisi, str. 207.

${ }^{45}$ Č. S. Pers, Pragmatizam, str. 24. 
U ovom kontekstu Habermasovo tumačenje Persovog učenja dolazi do interesantnih stavova. Neopragmatistički mislilac će veliku pažnju u delu knjige Saznanje $i$ interes u kome govori o filozofiji rodonačelnika pragmatizma posvetiti razmatranju toga na koji način se Persov pragmatizam, zagovarajući tezu o istraživačkom karakteru saznanja, odnosi prema tome kako se celokupna stvarnost „u celini tek konstituiše u uslovima procesa istraživanja“ . ${ }^{46}$ Iako naglašava da „Pers ne pada u objektivističko nastrojenje starijeg pozitivizma“, ali i da njegova epistemološka orijentacija „ne uključuje idealizam“ barklijevskog tipa, Habermas ističe da Pers ipak podrazumeva da "stvarnost postoji nezavisno od našeg faktičkog saznavanja““. ${ }^{47}$ Ne ulazeći u dublje razmatranje činjenice da se u Persovim stavovima ovog tipa zastupa određena verzija epistemološkog realizma, autor knjige Saznanje i interes primećuje da same Persove teze o istraživačkom karakteru saznanja postavljaju pitanje o tome na koji način postoji sam predmet saznanja. Budući da se predmet saznanja kao istraživanja zasniva na različitim misaonim operacijama svesti, on mora biti utemeljen na nečemu što samo nije posredovano mišljenjem, smatra Habermas, kako bi se u Persovom učenju izbegla „imanencija misaonog procesa koji se kreće u krugu““. ${ }^{4}$ Habermas ističe da se upravo u ovoj sferi neposredovanog može tražiti čovekov podsticaj za sprovođenje istraživačkih delatnosti koje bi rezultirale određenim znanjem. ${ }^{49}$ Rečeno jezikom Persovog pragmatizma, ono neposredovano pokreće sumnju, koja dovodi do revizije starih verovanja, pa se tako stalno približava ,pravom rešenju“ istraživačkih delatnosti (rešenju koje je, kao što ćemo ubrzo pokazati, čak sudbinski predodređeno). U potrazi za odgovarajućim teorijskim određenjem načina na koji se Pers u svojoj filozofiji odnosi prema ovoj „sferi neposredovanog“, Habermas naglašava da bi Persova pozicija svakako mogla bar govoriti o svojevrsnoj ,prinudi realnosti“, koja motiviše subjekt saznanja kao istraživanja da istraživačkim aktivnostima poboljša

\footnotetext{
${ }^{46}$ J. Habermas, Saznanje i interes, str. 128.

${ }^{47}$ Ibid., str. 129.

${ }^{48}$ Ibid., str. 134.

${ }^{49}$ Ibid., str. 136.
} 
svoje znanje o svetu koji ga okružuje. ${ }^{50} \mathrm{Na}$ koji način govoriti o ovoj „prinudi realnosti“, a istovremeno ostati veran tezama o istraživačkom karakteru saznanja, ne posežući za rešenjima poput zagovaranja postojanja svojevrsne „stvari po sebi“弦 - to je problem koji neopragmatistički teoretičar smatra najvećim izazovom Persovog filozofskog učenja. Koristeći kantovski pojam stvari po sebi, Habermas nema nameru da direktno neposredno upoređuje Kantovu i Persovu filozofiju, već želi da istakne da bi u Persovom učenju ovakvo naknadno unošenje izvan-iskustvene realnosti unelo probleme slične onima koje stvar po sebi izaziva u Kantovoj filozofiji.

Pored izloženog problema koji se tiče bivstvovanja predmeta saznanja kao istraživanja, Habermas tumačenju Persove filozofije pridružuje razmatranje još jednog stava rodonačelnika pragmatizma. Budući da se, prema Habermasu, Persov pragmatizam zasniva na premisi o kumulativnom rastu znanja u nauci, ovaj teoretičar će od učenja klasičnog pragmatiste očekivati da uz pomoć same teze o istraživačkoj prirodi saznanja objasni i fenomen naučnog napretka, a ne da činjenicu naučnog napretka prosto prihvati kao istorijsku okolnost vremena u kome živi. ${ }^{52}$ Ovu tezu će Habermas iskazati u kantovskom (Immanuel Kant) duhu: Pers „metodološki mora da dokaže uslove mogućnosti institucionalizovanog saznajnog napretka“. ${ }^{53}$ Međutim, prema neopragmatističkom filozofu, Persovi stavovi nam ne pomažu mnogo ukoliko tragamo za metodološkim zasnivanjem teze o naučnom napretku: ovaj teoretičar se uzda u to da će svako istraživanje, ukoliko se „dogura dovoljno daleko" dovesti do istog rezultata savesno sprovedenih istraživačkih delatnosti. ${ }^{54}$ Štaviše, poslednja tačka svakog istraživanja, prema samim Persovim rečima, određena je unapred, nalik „,sudbini“‘! ${ }^{55}$ Iako Habermas ovo Persovo pouzdanje na više mesta u svom tekstu

\footnotetext{
${ }^{50}$ Ibid., str. 136-137.

${ }^{51}$ Ibid., str.133-134.

${ }^{52}$ Ibid., str. 125-126, 147.

${ }^{53}$ Ibid., str. 127.

${ }^{54}$ Ibid., str. 125. Up. Č. S. Pers, Pragmatizam, Bonart, Nova Pazova, 2002, str. 49.

${ }^{55}$ Ibid., str. 50-51. J. Habermas, Saznanje i interes, str. 127.
} 
povezuje sa institucionalnim karakterom istraživanja, na osnovu koga istraživači međusobno komuniciraju i neposredno utiču jedni na druge u samom istraživačkom procesu, treba imati u vidu da Pers smatra da će istraživači doći do zajedničke finalne tačke čak i nezavisno jedan od drugog. ${ }^{56}$

Nakon ilustrovanja izloženih problema, Habermas u tekstu o Persovom pragmatizmu govori o načinima na koji klasični pragmatista može izaći na kraj s ovim izazovima. Pers može rešiti ovaj problem priznajući da postoji određena neiskustvena stvarnost pre i nezavisno od samog iskustva, a time pragmatističku tezu o istraživačkoj prirodi saznanja utemeljiti na izvesnom epistemološkom realizmu. Ovakvim rešenjem problema objektivnog postojanja stvarnosti Pers bi osujetio epistemološke pretenzije pragmatističkog razumevanja saznanja, budući da bi time otvorio jaz između istraživačkog tretmana stvarnosti i svojevrsne „stvari po sebi“ ${ }^{57}$ U rešavanju problema odnosa istraživačkih operacija i neiskustvene stvarnosti tada bi verovatno bilo neophodno prizvati u pomoć tradicionalnu epistemologiju. Međutim, Habermas ni u jednom delu svog teksta o Persovoj filozofiji ne tvrdi direktno da bi ovaj filozof jednostavno prihvatio poziciju koja bi zagovarala postojanje svojevrsne stvari po sebi, a kojom bi se utemeljio predmet saznanja kao istraživanja (bez obzira na to što i sam ukazuje na izvesnu Persovu tendenciju ka epistemološkom realizmu). Međutim, izgleda da već pomenuti delovi Persovih filozofskih tekstova sugerišu da je rodonačelnik pragmatizma ipak blizak i ovom teorijskom rešenju.

Sa druge strane, Habermas navodi da je moguće i drugo rešenje, rešenje „doslednog pragmatizma“, odnosno učenja koje bi neiskustvenu „prinudu realnosti“" protumačilo kao proizvod jedne faze istraživanja: ${ }^{.5}$ rečeno jezikom Persove filozofije, to bi bilo istraživačko stanje sumnje $u$ adekvatnu interpretaciju stvarnosti, a ne određeno stanje koje se tiče svojevrsne „stvari po sebi“, koja postoji nezavisno od subjekta istraživanja. Međutim, Habermas kaže: „Pers nije tako argumentovao“ -

\footnotetext{
${ }^{56}$ Ibid., str. 128. Č. S. Pers, Pragmatizam, str. 50.

${ }^{57}$ Ibid., str. 134-137, 143-144.

58 Ibid., str. 137.
} 
Pers ne bira nijedno od dva navedena rešenja, već bira treći put. ${ }^{59}$ Rešenje problema statusa neposredovane osnove saznanja ovaj teoretičar traži u proučavanju logike jezika, a ne logike istraživanja. ${ }^{60}$ Habermas smatra da mesto sholastičkog realizma u Persovom učenju treba upravo tražiti u kontekstu ovog jezičkog rešenja problema neposredovane osnove saznanja. ${ }^{61}$ Nakon izlaganja osnovnih stavova Persovog semiološkog učenja, Habermas zaključuje da se u slučaju Persovog jezičko-logičkog rešenja propagira realizam svojevrsnih „univerzalnih stanja stvari“, kao „univerzalnih veza, koje konstituišu stvarnost““. ${ }^{62}$ Zastupanjem mišljenja o realnom postojanju univerzalnih stanja stvari osigurava se već pomenuto sudbinsko predodređenje svih istraživačkih aktivnosti: ako univerzalna stanja stvari postoje realno, postoji finalna tačka ka kojoj streme sve aktivnosti saznanja kao istraživanja. ${ }^{63}$ Međutim, Persov pragmatizam se ovim poduhvatom zapravo svodi na „ontologizovanje jednog prvobitno metodološkog pitanja“, pa je time ovaj pragmatizam nedosledan, jer ne istrajava u rešavanju teorijskih problema iz perspektive teze o istraživačkom karakteru saznanja. ${ }^{64}$

\section{DŽEMSOVO UČENJE O PRAGMATIZMU KAO METODI I MOGUĆNOST RIGIDNOG TUMAČENJA PRAGMATIZMA NA OSNOVU OVOG UČENJA}

Iako se Habermas u knjizi Saznanje i interes pozabavio isključivo Persovim pragmatizmom i njegovom tendencijom ka „metodološkom pojmu istine“, razmotrimo u kojoj meri se Džemsovi stavovi u Pragmatizmu približavaju ovakvim teorijskim stremljenjima. Imajući u vidu filozofske domete Persovog pragmatizma, Džems preciznije određuje teorijske ciljeve sopstvenog pragmatističkog učenja, pa napominje da je pragmatizam najpre „samo metoda“, ali da se on sa

\footnotetext{
${ }^{59}$ Ibid.

${ }^{60}$ Ibid., str. 137-138, 145-146.

${ }^{61}$ Ibid., str. 143-144.

${ }^{62}$ Ibid., str. 144,145.

${ }^{63}$ Ibid., str. 145-146.

${ }^{64}$ Ibid., str. 146.
} 
podjednakim pravom može smatrati i ,teorijom istine““ ${ }^{65}$ Pragmatizmom kao metodom ovaj teoretičar pre svega imenuje pragmatistički odnos prema tradicionalnoj filozofiji, pri čemu je pragmatizam metoda „rešavanja metafizičkih sporova“, sporova do kojih dolazi u samoj filozofiji prilikom sučeljavanja suprotnih mišljenja. ${ }^{66}$ Tako Džems na početku svojih predavanja o pragmatizmu formuliše stav koji u njegovom učenju ima status sličan pragmatističkoj maksimi u Persovoj filozofiji: „Ako se nikakva praktična razlika [između pojmova, D. M.] ne može povući, onda alternative praktično znače istu stvar, i svaka je raspra uzaludna dokolica“. ${ }^{67}$ Ukazivanjem na ulogu koju pragmatizam ima u samom teorijskom diskursu, Džemsov pragmatizam predstavlja neposrednu preteču Rortijevog razumevanja uloge filozofije, koja tumačenju stvarnosti doprinosi tako što upoređuje „rečnike“ različitih epoha, kultura i filozofija. ${ }^{68}$

Ovako shvaćen Džemsov pragmatizam još uvek održava potpuni otklon od epistemologije koji je Habermas očekivao od Persovog pragmatizma. Budući da je sama indiferentna prema određenim filozofskim rešenjima, metoda „rešavanja metafizičkih sporova“ s istim se pravom može primeniti kako u metafizičkoj, tako i u antimetafizičkoj filozofiji. O ovom neutralnom karakteru pragmatističke metode svedoči i to što na početnom stupnju razmatranja pragmatizma Džems govori čak i o pomirenju nauke i metafizike, o njihovoj saradnji u tumačenju stvarnosti, „rame uz rame“. ${ }^{69}$ Pri tom nije sasvim jasno koji bi aspekti metafizičkog učenja zapravo opstali u ovom odnosu, budući da bi znatan deo metafizičkih teorijskih motiva bio eliminisan uz pomoć prethodno navedene Džemsove „maksime“ o adekvatnom razumevanju značenja pojmova. Nedvosmisleno ostavljanje prostora za metafiziku vidljivo je i u Džemsovom interpretiranju ilustracije kojom italijanski filozof Đovani Papini (Giovanni Papini) određuje prirodu pragmatizma: Papini

\footnotetext{
${ }^{65}$ V. Džems, Pragmatizam, str. 37, 39.

${ }^{66}$ Ibid., str. 34.

${ }^{67}$ Ibid., str. 34.

${ }^{68}$ R. Rorti, Konsekvence pragmatizma, str. 87-91.

${ }^{69}$ V. Džems, Pragmatizam, str. 37.
} 
upoređuje pragmatizam sa hodnikom $\mathrm{u}$ jednom hotelu sa bezbroj odaja, a Džems u jednu od tih odaja smešta i metafizičara. ${ }^{70}$

Izgleda da početni oblik Džemsovog pragmatističkog učenja ostavlja prostor za metafiziku da bi ovaj teoretičar obezbedio pogodno tlo za povezivanje religije i pragmatizma. Tako se vernik takođe može pronaći u jednoj od odajâ u Džemsovoj interpetaciji Papinijeve ilustracije pragmatizma, a zatim se religija usaglašava sa pragmatizmom i Džemsovim tvrdnjama da pragmatizam „nije tako materijalistički nastrojen kao što je običan empirizam“ i da može da bude „srećan izmiritelj empiričkih načina mišljenja i religioznijih zahteva ljudskog bića“. ${ }^{71}$ Džems nedvosmisleno tvrdi da se religija u pragmatizmu može prihvatiti ukoliko ima adekvatne praktične posledice u svakodnevnom životu, pri tom misleći na one posledice koje se tiču pružanja „religiozne utehe“ ${ }^{72}$ ali da se njeni stavovi moraju uskladiti sa ostatkom naših verovanja. Insistiranje na usklađivanju religijskih stavova i ostatka verovanja Džems svakako formuliše po uzoru na slične Persove zahteve izložene u duhu naučne metodologije. Međutim, da bi se jedna religijska koncepcija usaglasila sa ostalim idejama koje je moguće prihvatiti iz Džemsove pragmatističke perspektive, ona bi se morala „pročistiti“ od „prastvari, prvih principa, kategorija, zamišljenih nužnostii“, ${ }^{73}$ pa bi takva religija bila redukovana na pokretanje prostih psihičkih mehanizama koji obezbeđuju utehu (pod pretpostavkom da je te mehanizme uopšte moguće odvojiti od ontoloških, kosmoloških, etičkih i ostalih koncepcija u jednoj religiji, koncepcija koje mogu imati karakter nužnosti i apriornosti). Sa druge strane, prihvatanje jeftinog efekta u vidu pružanja utehe ove vrste, koju može proizvesti neko religiozno verovanje, može biti i u direktnoj suprotnosti sa osnovnim načelima te religije.

Iako Džemsovo učenje o pragmatizmu kao metodi uspešno održava otklon od određenog epistemološkog opredeljenja i time uspeva da bude „dosledno“ u Habermasovom i Rortijevom smislu te reči, način

\footnotetext{
${ }^{70}$ Ibid., str. 38 .

${ }^{71}$ Ibid., str. 46.

${ }^{72}$ Ibid., str. 47, 48.

${ }^{73}$ Ibid., str. 39.
} 
na koji ovaj teoretičar prikazuje pragmatističku filozofiju ne uspeva da istakne ovo njeno preimućstvo, već dobija i jednu problematičnu konotaciju. Ukoliko nam Džemsovo prihvatanje religije zarad psihičke utehe ili motivacije koju ona može da pruži već u određenoj meri liči na rigidno razumevanje pragmatizma, prema kome bi pragmatizam propagirao izvlačenje neke koristi gde god je to moguće, sledeća Džemsova formulacija iz korišćenog prevoda njegovog Pragmatizma može nam izgledati kao definitivno utemeljenje takve interpretacije ove filozofske orijentacije. Govoreći o pragmatističkoj metodi, Džems kaže: „Morate izvesti iz svake reči njenu praktičnu vrednost, i to vrednost u gotovu novcu [practical cash-value], i da je isprobate u okviru svoga iskustva“. ${ }^{74}$ Navedeno mesto iz teksta prevoda moglo bi potvrditi sumnje njegovih čitalaca $\mathrm{u}$ to da pragmatizam uzima $\mathrm{u}$ obzir isključivo neposrednu praktičnu korist nekog predmeta, budući da se navedenim stavom ne ukazuje samo na određenu korist koja proizilazi iz upotrebe nekog predmeta, već i na to da se ta korist može meriti novčanom vrednošću jednog predmeta. Međutim, za problematičnu formulaciju odgovoran je sâm Džems, a ne prevodilac srpskog izdanja Pragmatizma: Džemsova formulacija „cash-value“ zapravo predstavlja metaforu. ${ }^{75}$ „Cash-value“ nije tehnički termin Džemsove filozofije, već jedna neobavezna, kolokvijalna formulacija; međutim, sâm Džems je revnosno i bez dodatnog obrazloženja koristio u više svojih tekstova, pa je umnogome doprineo da se pragmatizmu već u doba njegovog najvećeg uspona pripiše jedna rigidna interpretacija. ${ }^{76}$ Tako je pragmatizam smatran i filozofijom koja u potpunosti izražava i afirmiše vrednosti (surovog) američkog kapitalizma. ${ }^{77}$ Upotrebom ove fraze, Džems nespretno pokušava da referiše na neraskidivi odnos značenja koje pripisujemo nekoj reči i svakodnevne upotrebe predmeta koji ta reč imenuje ili bliže određuje - referenca prećutno podrazumeva da se dobar

${ }^{74}$ Ibid., str. 38. W. James, Writings 1902-1910, Literary Classics of the United States Inc., New York, 1987, str. 509.

${ }^{75}$ G. Cotkin, "William James and the Cash-Value Metaphor" u: Etc: A Review of General Semantics Vol. 42, 1985, str. 37.

${ }^{76}$ Ibid., str. 37-38.

${ }^{77}$ Ibid., str. 37. 
deo naših svakodnevnih aktivnosti sastoji u robno-novčanoj razmeni, a da vrednost nekog predmeta često određujemo preko novčane vrednosti. Međutim, iako je navedeni tekst predavanja pisan slobodnijim stilom jer je namenjen široj publici, ova metafora je na ovom mestu u Džemsovoj knjizi suviše uronjena u filozofsku problematiku da bi se razumela uz pomoć povezivanja sa praksama svakodnevnog života, pa je njome Džems naveo na pogrešan trag čak i čitaoce originalnog teksta na engleskom jeziku.

\section{ISTRAŽIVAČKI KARAKTER SAZNANJA I PROBLEMI USVAJANJA TRADICIONALNIH EPISTEMOLOŠKIH REŠENJA U DŽEMSOVOM PRAGMATIZMU}

Izvodeći konsekvence iz svog učenja o pragmatizmu kao metodi, Džems ukazuje na to da i samo saznanje ima istraživačku strukturu, pa se i o njegovom učenju može govoriti iz perspektive Habermasove teze o „metodološkom pojmu istine“ u pragmatizmu. Prema Džemsu, pragmatistička metoda zagovara redukciju saznanja na ona tumačenja stvarnosti koja imaju adekvatnu potporu u vidu posledicâ u samom životu subjekta saznanja, pa teze o stvarnosti koje subjekt iznosi postaju ,oruđe istraživanja, a ne odgovori na zagonetke“ ${ }^{78}$ Određeni aspekti poglavlja o pragmatističkom shvatanju istine u Pragmatizmu (u kome Džems više nijednom ne pominje pragmatističku metodu) takođe direktno slede dosledno pragmatistički karakter stavova o metodi. Tako Džems govori da pragmatizam odbacuje statički karakter istine koji zagovara tradicionalna epistemologija: istina koja ima statički karakter jedna je i nepromenljiva, bilo da se njena statičnost opravdava uz pomoć različitih varijanti teorije korespondencije, ili se određeni stavovi smatraju istinitim „kad god su ono što Bog smatra da treba da mislimo“. ${ }^{79}$ Dinamički karakter pragmatističkog pojma istine ogleda se upravo u istraživačkom odnosu koji uspostavljamo sa predmetom iskustva, a ovaj odnos Džems

\footnotetext{
${ }^{78}$ V. Džems, Pragmatizam, str. 38.

${ }^{79}$ Ibid., str. 116.
} 
ilustruje referišući na osnovne pojmove i stavove naučne metodologije. ${ }^{80}$ Dok je Džems u poglavlju o pragmatističkoj metodi istinu izjednačavao sa verovanjem, gotovo doslovno koristeći teorijske domete Persovog učenja, ${ }^{81}$ sada, u poglavlju o pragmatističkoj teoriji istine, ,istinito“ izjednačava sa „proverljivim“. ${ }^{82}$ Način proveravanja nekog stava ne tiče se samo praktičnih posledica koje proizilaze iz nekog verovanja, nego i mogućnosti usklađivanja tog verovanja sa prethodno prihvaćenim stavovima. U odnosu prema ostatku iskustva, pojam istine u Džemsovom učenju dobija i svojevrsno negativno određenje: svako verovanje je „istinito“ dok se ne pojavi neko drugo verovanje koje bi ga dovelo u pitanje, a time i ubacilo u proces proveravanja i novog istraživanja. ${ }^{83}$

Određene nedoslednosti u samom Džemsovom pragmatističkom učenju dovode $u$ pitanje samo Džemsovo sprovođenje pragmatističke ideje o istraživačkom karakteru iskustva. U kontekstu govora o važnosti svojevrsne istinoljubivosti u činu saznanja kao istraživanja, Džems iznosi naizgled neproblematičnu tezu prema kojoj su istinita verovanja korisna „dugoročno“ (in the long run), odnosno (rečeno kolokvijalnim jezikom i poigravajući se sa nesrećnom Džemsovom metaforom „cash-value“), istinitost se ,isplati na duge staze“, dok su neistinita verovanja dugoročno štetna. ${ }^{84}$ Međutim, ovu „zdravorazumsku“ tvrdnju teško je usaglasiti sa prethodno iznetim Džemsovim pragmatističkim tezama. Određeno verovanje je istinito ako „radi“ (tj. proizvodi adekvatne posledice) i ako još uvek nije dovedeno u pitanje na osnovu drugih verovanja; ${ }^{85}$ sledstveno tome, ono je istinito $\mathrm{u}$ određenom trenutku, $\mathrm{u}$ konkretnom korpusu iskustva, u jasno definisanoj ulozi koju to znanje ima u aktuelnom svakodnevnom životu. O „dugoročnoj“ istini prosto nije moguće govoriti sa pragmatističkog epistemološkog stanovišta, jer bi već

\footnotetext{
${ }^{80}$ Ibid., str. 117.

${ }^{81}$ Ibid., str. 49-50.

${ }^{82}$ Ibid., str. 117, 118.

${ }^{83}$ Ibid., str. 120, 123.

${ }^{84}$ W. James, Writings 1902-1910, str. 587. U korišćenom tekstu prevoda javlja se fraza „na kraju krajeva“ koja ne ilustruje na pravi način smisao Džemsove tvrdnje. Up. V. Džems, Pragmatizam, str. 132.

${ }^{85}$ Ibid., str. 124-125.
} 
neko naredno verovanje, naknadno iskustvo koje „radi“ na još adekvatniji način, predstavljalo povod za preispitivanje te istine i eventualno lišavanje prethodnog verovanja njegove istinitosti. Ako ovu tezu nije moguće spojiti sa istraživačkim karakterom saznanja, koji je prethodnim tvrdnjama Džems dosledno zagovarao, sa kog epistemološkog stanovišta Džems govori o „dugoročnoj“ istini? Rečeno $u$ duhu Persovog izjednačavanja istine i verovanja, ukoliko je verovanje sada korisno, ono je sada $i$ istinito, $i$ obrnuto.

Sličan problematičan karakter u Džemsovom istraživačkom razumevanju iskustva može se naći i u njegovoj tezi o „istini u mogućim situacijama“. ${ }^{86}$ Prema Džemsu, „bezmalo svaki predmet može jednog dana da postane privremeno značajan“, pa treba razmišljati o njegovim posledicama koje se mogu javiti u nekim budućim okolnostima. ${ }^{87}$ Međutim, iako se ovaj stav može interpretirati po uzoru na obrasce naučne metodologije koji se tiču predviđanja, obrasce prema kojima se, primera radi, određeni zaključci formulišu pre nego što se mogu ostvariti adekvatni uslovi za njihovu eksperimentalnu proveru, Džemsova teza o „istini u mogućim situacijama“ nije spojiva sa njegovim insistiranjem na tome da se proveravanje neke teze uvek tiče statusa nekog verovanja „negde i na nekom određenom mestu, bez čega se zgrada istine ruši kao finansijski sistem koji nema nikakve stvarne podloge (...) “ ${ }^{88}$ Iz izloženog prigovora ne sledi da predviđanje posledica koje se mogu javiti u budućim okolnostima nema nikakvu vrednost za jedno pragmatističko učenje, već jedino proizilazi to da se tvrdnje o ovim mogućim posledicama, na osnovu ostalih Džemsovih stavova, ne mogu u pravom smislu smatrati ,istinitim“ tvrdnjama.

Poslednja uporišna tačka dosledno pragmatističkog tumačenja iskustva u Džemsovom učenju može se pronaći $u$ interesantnom Džemsovom upoređivanju istraživačkog karaktera iskustva sa snežnom loptom koja raste. Kao što se snežna lopta istovremeno povećava time što je „dečaci guraju“ ali i zahvaljujući snežnoj površini na kojoj se kotrlja,

\footnotetext{
${ }^{86}$ Ibid., str. 118.

${ }^{87}$ Ibid.

${ }^{88}$ Ibid., str. 120.
} 
tako i iskustvo, prema Džemsu, istovremeno raste uz pomoć „činjenica“ kao iskustvene datosti i postupaka saznanja kao istraživanja na osnovu kojih ove činjenice dobijaju odgovarajuće mesto u korpusu iskustva. ${ }^{89}$ Kao i u slučaju snežne lopte, u kome se ne može jasno odvojiti u kojoj meri samo guranje lopte doprinosi njenom rastu, a u kojoj meri to čini snežna površina, tako se i u rastu znanja udeo iskustvene datosti ne može odvojiti od udela istraživačkih postupaka.

Međutim, u rešavanju rafiniranijih problema saznanja, Džems ne uspeva da zadrži neutralno epistemološko stanovište za koje je podigao temelj svojim pragmatističkim učenjem. Tako Džems već u poglavlju o pragmatističkom shvatanju istine pribegava jednom hjumovskom rešenju u razmatranju statusa takozvanih ,duhovnih ideja““, ${ }^{90}$ a u posebnom smislu i prirode matematičkih principa. Džems sada direktno razdvaja znanje koje se tiče činjenica od znanja koje ima duhovno poreklo, i time gotovo doslovno sledi Hjuma. ${ }^{91}$ Bez obzira na to što Džems smatra da istraživačku strukturu saznanja možemo uočiti i u našem odnošenju prema duhovnim idejama, on ipak ovim stavom pravi prvo otvoreno odstupanje od zagovaranja istraživačkog karaktera saznanja, budući da se istraživačkim metodama ne može dosegnuti do neposredne očiglednosti, apriornosti i večnosti koje Džems pripisuje duhovnim idejama - štaviše, nabrojane odredbe duhovnih ideja upravo su oni aspekti filozofske pojmovne aparature od kojih je u prethodnom poglavlju Džemsova pragmatistička metoda „odvraćala pogled“. ${ }^{92}$

Potpuno udaljavanje od očekivanog pragmatističkog otklona od određenog epistemološkog opredeljenja Džems zatim vrši u „Esejima o radikalnom empirizmu“, napisanim pre, a objavljenim nakon Pragmatizma. ${ }^{93} \mathrm{U}$ ovim tekstovima, američki teoretičar zastupa radikalno

\footnotetext{
${ }^{89}$ Ibid., str. 129.

${ }^{90}$ Ibid., str. 121.

${ }^{91}$ Up. D. Hume, Istraživanje o ljudskom razumu, Kultura, Zagreb, 1956, str. 37.

92 V. Džems, Pragmatizam, str. 39.

${ }^{93}$ Up. G. Russell, "William James", u: The Stanford Encyclopedia of Philosophy (Winter 2017 Edition), Edward N. Zalta (ur.), https://plato.stanford.edu/archives/win2017/entries/james.
} 
fenomenalističko stanovište, ${ }^{94}$ prema kome se ne samo čulna datost, već svi aspekti samog saznanja (štaviše, celokupnog života subjekta, uključujući i emocije), sve do svesti same (uzete kako u smislu subjekta saznanja, tako i u smislu samog saznajnog čina), mogu smatrati samo predmetima iskustvenog života i saznanja $u$ vidu jedne njegove „funkcije“ ili „procesa“. ${ }^{95} \mathrm{Ne}$ ulazeći u detaljniju eksplikaciju Džemsove epistemologije u pomenutim esejima, koja u mnogim aspektima i dalje sledi Hjuma ${ }^{96}$ pomenimo samo to da iako i sâm teži da poveže sopstvene teze o monizmu iskustva sa pragmatističkim razumevanjem istine, ${ }^{97}$ Džems nužno napušta tezu o istraživačkom karakteru saznanja, budući da već i početnom fenomenalističkom tezom zastupa mišljenje do koga nije moguće dosegnuti samim saznanjem kao istraživanjem.

\section{ZAKLJUČAK}

$\mathrm{Na}$ osnovu problema koje izazivaju prethodno izložene koncepcije dvojice teoretičara klasičnog pragmatizma, približavamo se zaključku da se Habermasova i Rortijeva teza o „doslednom pragmatizmu“, koji bi ostao u granicama zastupanja istraživačkog karaktera saznanja, ne posežući za rešenjima tradicionalne epistemologije, ne može na odgovarajući način derivirati iz samih tekstova Persa i Džemsa. Ne samo da u Persovom pragmatizmu postoje određene teorijske tendencije usmerene ka epistemološkom, kao i sholastičkom realizmu, koje je i Habermas uočio u pomenutoj knjizi, već se Persova filozofska koncepcija udaljava od teze o istraživačkom karakteru saznanja i u drugim aspektima njegovog učenja, poput stavova

94 O realizmu i fenomenalizmu videti u: Dž. Dansi, Uvod u savremenu epistemologiju, Plato, Beograd, 2006, str. 163-179.

${ }^{55}$ V. Džems, „Eseji o radikalnom empirizmu“ u: V. Džems, Pragmatizam, str. $176,179,180$.

${ }^{96}$ Up. Hjumove stavove o svesti i subjektu saznanja u: G. Dicker, Hume's Epistemology \& Metaphysics, Routledge, London and New York, 2001, str. 1920.

${ }^{97}$ V. Džems, „Eseji o radikalnom empirizmu“ u: V. Džems, Pragmatizam, str. $184,186$. 
o ,instinktivnim verovanjima“ i „sudbonosnom“ predodređenju svakog saznanja. Sa druge strane, rečeno u duhu Habermasove kritike Persa, Džems je takođe svojim fenomenalizmom izvršio jednu naknadnu „epistemologizaciju“ prethodno izloženih teza o istraživačkom karakteru saznanja u Pragmatizmu, u kojima su određene tvrdnje, poput stava o „dugoročnim“ istinama i učenja o „duhovnim idejama“ već dovodile u pitanje istraživački karakter saznanja u njegovoj filozofiji. Sledstveno tome, već pomenuti Rortijev stav da Džems ne traži „epistemološko rešenje“ za problem iskustva može se prihvatiti samo ukoliko se Džemsovo učenje „pročisti“ od problematičnih Džemsovih epistemoloških izleta. ${ }^{98} \mathrm{U}$ nekom budućem radu, potrebno je razmotriti da li probleme izložene vrste izbegava kompleksnije Djuijevo pragmatičko učenje, izloženo u knjizi Logika, teorija istraživanja, kao i to u kojoj meri Habermasove i Rortijeve neopragmatističke tendencije zaista počivaju na teorijskom nasleđu Persove, Džemsove i Djuijeve filozofije. ${ }^{99}$

\section{LITERATURA}

Cotkin, G. „William James and the Cash-Value Metaphor“ u: Etc: A Review of General Semantics Vol. 42, 1985.

Dansi, Dž. Uvod u savremenu epistemologiju, Plato, Beograd, 2006.

Dicker, G. Hume's Epistemology \& Metaphysics, Routledge, London and New York, 2001.

Djui, Dž. Logika, teorija istraživanja, Nolit, Beograd, 1962.

Džems, V. Pragmatizam, Kosmos, Beograd, 1940.

Guignon, C., Hiley, D. R. (ur.), Richard Rorty, Contemporary Philosophy in Focus, Cambridge University Press, Cambridge, 2003.

Habermas, J. Erkenntnis und Interesse, Suhrkamp, Frankfurt am Main, 1991.

Habermas, J. Saznanje i interes, Nolit, Beograd, 1975.

Hume, D. Istraživanje o ljudskom razumu, Kultura, Zagreb. 1956

\footnotetext{
${ }^{98}$ R. Rorti, Konsekvence pragmatizma, str. 301-303.

${ }^{99}$ Ovaj rad je u velikoj meri baziran na jednom delu mog master rada „Djuijeva pragmatistička teorija estetskog iskustva“, odbranjenog 19.09.2016. na Odseku za filozofiju Filozofskog fakulteta u Novom Sadu.
} 
James, W. Writings 1902-1910, Literary Classics of the United States Inc., New York, 1987.

Legg, C. i Hookway, C. „Pragmatism“, u: The Stanford Encyclopedia of Philosophy (Spring 2019 Edition), Edward N. Zalta (ur.), https://plato.stanford.edu/archives/spr2019/entries/pragmatism.

Milenković, D. „Djuijevo pragmatističko poimanje umetnosti u knjizi Art as Experience“, Arhe 26/2016.

Moore, E. C. „The Scholastic Realism of C. S. Peirce“, u: Philosophy and Phenomenological Research, Vol. 12, No. 3 (Mart 1952)

Pers, Č. S. Izabrani spisi, BIGZ, Beograd, 1993.

Pers, Č. S. Pragmatizam, Bonart, Nova Pazova, 2002.

Ramberg, B. „Richard Rorty“, u: The Stanford Encyclopedia of Philosophy (Spring 2009 Edition), Edward N. Zalta (ur.), https://plato.stanford.edu/entries/rorty/

Rorti, R. Konsekvence pragmatizma, Nolit, Beograd, 1992.

Rorty, R. Consequences of Pragmatism, University of Minessota Press, Minneapolis, 1994.

Russell, G. „William James“, u: The Stanford Encyclopedia of Philosophy (Winter 2017 Edition), Edward N. Zalta (ur.), https://plato.stanford.edu/archives/win2017/entries/james.

Simović, S. „Konsekventni neopragmatizam“, u: R. Rorti, Konsekvence pragmatizma, Nolit, Beograd, 1992.

Životić, M. Pragmatizam i savremena filozofija, Nolit, Beograd, 1966.

\author{
DUŠAN MILENKOVIĆ \\ University of Niš, Faculty of Philosophy
}

\title{
„METHODOLOGICAL CONCEPT OF TRUTH“ AND EPISTEMOLOGICAL TENDENCIES IN CLASSICAL PRAGMATISM OF CH. S. PEIRCE AND W. JAMES
}

\begin{abstract}
In this paper, I analyze Habermas' interpretation of Peirce's pragmatism and its tendency to apply the theoretical approach of scientific methodology in solving problems of epistemology. Following this interpretation, I try to show that Peirce in his most famous essays fails to talk about knowledge solely from the perspective of scientific research methods, despite his open criticism of traditional philosophy. Although Habermas does not examine in his
\end{abstract}


book Knowledge and Human Interests the philosophy of William James, in this paper, I discuss to what extent this author promotes the thesis of the „methodological concept of truth“, both in his critique of traditional philosophy and his own theory of knowledge. The paper comes to the conclusion that Habermas's ,consistent pragmatism“ can be found in neither Peirce's nor James' philosophy, since both authors rely on the theoretical solutions taken from traditional epistemology, without remaining within the scope of the „methodological concept of truth“.

Keywords: Ch. S. Peirce, J. Habermas, W. James, pragmatism, metodological concept of truth

Primljeno: 25.8.2019.

Prihvaćeno: 2.11.2019. 